๑Т. В. Стоєва, О. В. Решетіло, Н. Л. Весілик, Т. І. Рижикова, О. Ю. Миронов Одесъкий національний медичний університет

\title{
РОЛЬ ГЕНЕТИЧНОГО ПОЛІМОРФІЗМУ БІЛКА ФІЛАГРИНУ ПРИ ПОЕДНАННІ АТОПІЧНОГО ДЕРМАТИТУ ТА БРОНХІАЛЬНОЇ АСТМИ У ДІТЕЙ
}

\begin{abstract}
Мета дослідження - вивчити особливості поєднаного перебігу атопічного дерматиту (АД) і бронхіальної астми (БА) у дітей за умов генетичного поліморфізму білка фрілагрину.

Матеріали та методи. Вивчено перебіг фрілагринасоційованого атопічного дерматиту та супутньої бронхіальної астми у дітей віком від 3 до 12 років $(n=51)$, сорормовано репрезентативні групи: діти 3 атопічним дерматитом $(n=31)$ та діти 3 атопічним дерматитом та супутньою бронхіальною астмою /БА (n=20). Поліморфізм гена фрілагрину визначали, досліджуючи букальний епітелій за методом Делапорта. Сенсибілізацію до алергенів встановлювали на основі рівня специфічних IgE. Вплив захворювання на якість життя (ЯЖ) дітей проводили за допомогою опитувальника CDLQI (індекс якості життя дитини при дерматологічних захворюваннях).
\end{abstract}

Результати дослідження та їх обговорення. В обстежених дітей найчастіше $((78,4 \pm 5,76) \%)$ при поєднанні АД і БА спостерігали варіант поліморфізму R501X, варіант із делецією 2282del4 реєстрували в $(7,8 \pm 3,76) \%$, а компаундну гетерозиготність - у $(13,7 \pm 4,81) \%$ пацієнтів. Продемонстровано асоціативний зв'язок поліморфізму фрілагрину із тяжким перебігом АДу дітей $(54,9 \pm 6,97) \%)\left(x^{2}=16,2, p<0,05\right)$. Достеменної різниці за молекулярними характеристиками гена фрілагрину в групах порівняння не встановлено. В обох групах спостерігали ранню маніфестацію атопічного дерматиту. Встановлено, що в обох групах переважала полісенсибілізація до епідермальних, грибкових алергенів та Dermatofagoideus; харчову сенсибілізацію в групі АД спостерігали частіше, тоді як у групі АД/БА переважала пилкова сенсибілізація. Оцінюючи медико-

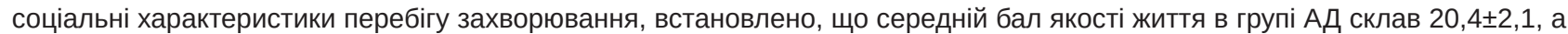

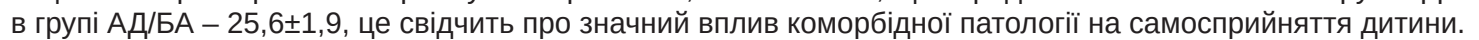

Висновки. Рання маніфестація атопічного маршу в дітей з поліморфізмом у гені білка фрілагрину потребує вживання заходів задля відновлення епідермального бар'єра шкіри, що запобігатиме транскутанному проникненню алергенів і ранній сенсибілізації організму.

Ключові слова: діти; атопічний дерматит; бронхіальна астма; фрілагрин.

\section{РОЛЬ ГЕНЕТИЧЕСКОГО ПОЛИМОРФИЗМА БЕЛКА ФИЛАГРИНА ПРИ СОЧЕТАНИИ АТОПИЧЕСКОГО ДЕРМАТИТА И БРОНХИАЛЬНОЙ АСТМЫ У ДЕТЕЙ}

Цель исследования - изучить особенности сочетанного течения атопического дерматита и бронхиальной астмы у детей в условиях генетического полиморфизма белка фрилагрина.

Материалы и методы. Изучено течение фрилагринассоциированного АД и сопутствующей бронхиальной астмы у детей 3-12 лет (n=51), ссрормированы репрезентативные группы: дети с атопическим дерматитом ( $\mathrm{n=31}$ и дети с атопическим дерматитом и сочетанной бронхиальной астмой $(\mathrm{n}=20)$. Полиморфизм гена фрилагрина выявляли, исследуя буккальный эпителий по методу Делапорта. Сенсибилизацию к аллергенам определяли на основании уровня специфических IgE. Изучение влияния заболевания на качество жизни (КЖ) детей проводили с помощью опросника CDLQI (индекс качества жизни ребенка при дерматологических заболеваниях).

Результаты исследования и их обсуждение. У обследованных детей чаще всего $((78,4 \pm 5,76) \%)$ при сочетании АД и БА наблюдали вариант полиморфизма $R 501 X$, вариант с делецией $2282 d e / 4$ регистрировали $(7,8 \pm 3,76) \%$, а компаундную гетерозиготность - у $(13,7 \pm 4,81) \%$ пациентов. Продемонстрировано ассоциативную связь полиморфизма фрилагрина с тяжелым течением АД у детей $\left((54,9 \pm 6,97) \%\left(\chi^{2}=16,2, p<0,05\right)\right.$. Истинного различия по молекулярным характеристикам гена филагрина в группах сравнения не установлено. В обеих группах наблюдали раннюю манифестацию атопического дерматита. Установлено, что в обеих группах преобладала полисенсибилизация к эпидермальным, грибковым аллергенам и Dermatofagoideus; пищевую сенсибилизацию в группе АД наблюдали чаще, в противовес в группе АД/БА преобладала пыльцевая сенсибилизация. Оценивая медико-социальные характеристики течения заболевания, установлено, что сред-

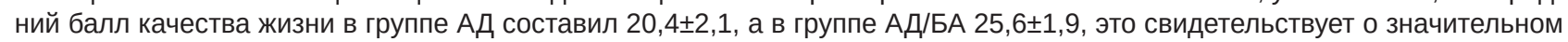
влиянии коморбидной патологии на самовосприятие ребенка.

Выводы. Ранняя манифестация атопического марша у детей с полиморфизмом в гене белка фрилагрина требует принятия мер для восстановления эпидермального барьера кожи, что предотвратит транскутанное проникновение аллергенов и раннюю сенсибилизацию организма.

Ключевые слова: дети; атопический дерматит; бронхиальная астма; фрилагрин.

THE ROLE OF GENETIC POLYMORPHISM OF FILAGRIN PROTEIN IN THE COMBINATION OF ATOPIC DERMATITIS AND BRONCHIAL ASTHMA IN CHILDREN

The aim of the study - to investigate the features of the combined course of atopic dermatitis and bronchial asthma of children under the conditions of genetic polymorphism of the protein filagrin.

Materials and Methods. The course of filagrin-associated AD and comorbid bronchial asthma of children 3-12 years ( $n=51$ ) was studied, representative groups were formed: children with atopic dermatiti $(n=31)$, and children with atopic dermatitis and comorbid bronchial asthma AD/BA $n=20$ ). Filagrin gene polymorphism was determined by examining the buccal epithelium by the Delaport method. Sensitization to allergens was adopted on the basis of the level of specific $\lg \mathrm{E}$. The impact of the disease 
on the quality of life (QOL) of children was performed using the CDLQI questionnaire (index of quality of life of the child at dermatological diseases).

Results and Discussion. Examination of children who most often had combining AD and asthma (78.4 \pm 5.76$) \%$ showed there was a variant of polymorphism R501X, a variant with a deletion of 2282 del 4 was registered in $(7.8 \pm 3.76) \%$, and compound heterozygosity - in $(13.7 \pm 4.81) \%$ of patients. The associative connection of filagrin polymorphism with severe AD of children was demonstrated in children $(54.9 \pm 6.97) \%(x 2=16.2, p<0.05)$. No significant difference in the molecular characteristics of the filagrin gene in the comparison groups was found. Early manifestation of atopic dermatitis was observed in both groups. It was found that in both groups polysensitization to epidermal, fungal allergens, and Dermatofagoideus prevailed; food sensitization in the $A D$ group was more common, in contrast, in the AD/BA group was dominated by pollen sensitization. Assessing the medical and social characteristics of the disease, the average quality of life in the group of $A D$ was (20.4 \pm 2.1$)$, and in the group of $A D / B A$ (25.6 \pm 1.9$)$, which indicates a significant impact of comorbid pathology on the child's self-perception.

Conclusions. Early manifestation of atopic march of children with polymorphism in the filagrin protein gene requires measures to restore the epidermal barrier of the skin, which will prevent transcutaneous penetration of allergens and early sensitization of the body.

Key words: children; atopic dermatitis; bronchial asthma; filagrin.

ВстУП. Поширеність алергічних захворювань неухильно збільшується у всьому світі, при цьому зберігається тенденція до зростання складності й тяжкості алергічних процесів у дитячому віці.

Останнім часом досягнуті значні успіхи в розумінні патофрізіології алергії завдяки застосуванню молекулярної діагностики, імунофенотипування, тканинної інженерії та вивченню епідермальних наноструктур. Саме ці дослідження продемонстрували, що в основі алергічних процесів лежать складні гетерогенні патофрізіологічні механізми, що охоплюють різні фенотипи і ендотипи патології, що визначають розвиток і подальший прогноз захворювання.

Особливе місце в структурі алергічних захворюваннь займає атопічний дерматит (АД), який є одним із найпоширеніших запальних захворювань шкіри і спостерігається в дитячому віці з частотою 15-20\%. Почавшись часто вже в ранньому віці, захворювання має не тільки виражені клінічні прояви, а й істотно позначається на якості життя дитини.

Хоча на сьогодні досить глибоко вивчено етіопатогенетичні механізми, що характеризують розвиток алергічної патології, остаточно не розкритими залишаються питання значущості неімунних механізмів у патофрізіології та розвитку атопічного маршу (AM).

Наразі доведена роль генетично детермінованих порушень, які створюють імунопатофрізіологічну платсрорму для реалізації атопії, гіперчутливості до алергенів й неспецифічних подразників, гіперпродукції медіаторів запалення при алергічних станах [1]. Утім наведених патогенетичних аспектів недостатньо для повного пояснення особливостей запальних процесів у шкірі, що відбуваються при АД та прогресуванні атопічного маршу. Ймовірно, саме порушення на молекулярному рівні лежать в основі неспроможності епідермісу забезпечувати бар'єрну фрункцію й запобігати транскутанному проникненню алергенів, що зрештою фрормує умови для фрормування хронічного запального процесу в шкірі та бронхах.

На сьогодні оприлюднено дані щодо участі 26 генів у розвитку запалення при атопії. Для більшості з них позначений зв'язок $з$ тим чи іншим алергічним станом [2]. За рекомендаціями інструкції з геномних та епігенетичних досліджень GWAS (genome-wide association studies), гени, що асоційовані з алергічними хворобами, прийнято поділяти на дві групи: гени шкірного бар'єру та гени імунної відповіді. У деяких пацієнтів $з$ алергопатологією обидва напрямки перетинаються, тим самим ініціюючи ланцюг запалення, який відповідатиме за розвиток певних клінічних нозоформ - АД, бронхіальна астма (БА), алергічний риніт (AP) - або їх поєднання [3-5].

У групі генів шкірного бар'єру особливе місце посідає ген білка фрілагринку (filament aggregating protein - FLG), який відповідає за регуляцію епідермального гомеостазу [6]. Саме завдяки білку фрілагринку фрормується білково-ліпідна структура рогового шару, відбувається дифреренціація кератиноцитів, створюється бар'єр, що перешкоджає втраті вологи і потраплянню алергенів і мікроорганізмів [7]. FLG - продукт протеолітично зміненого просрілагрину, попередника, що містить 324 множинні срілагринові одиниці та знаходиться в кератогіалінових гранулах. Доведено, що саме проміжний фріламентасоційований білок поєднує волокна кератину в епідермісі. За умов алергічного процесу кератиноцити порушеного бар'єру виділяють імунні ад'юванти, що активують дозрівання клітин Лангерганса або дендритних клітин, а також впливають на їх здатність скеровувати поляризацію «наївних» Th-лімфоцитів і, відповідно, впливати на характер Th-відповіді. Ключові структурні білки верхнього шару епідермісу, що беруть участь в зроговінні, закодовані на хромосомі 1q21, саме в цьому локусі знайдений ген, що кодує фрілагрин $[8,9]$. Тому поліморфізм у гені $F L G$ $€$ найважливішим генетичним чинником розвитку АД, а ймовірно і атопічного маршу взагалі [10] через доведену роль мутації гена FLG на рівні 1q21, що зумовлює порушення синтезу фрілагрину, індукуючи при цьому розвиток не лише АД, але й бронхіальної астми [1, 11]. Триває пошук становлення ролі десректів білка фрілагрину в сприянні розвитку БА у дітей [8].

Наразі триває активне вивчення поліморфрізму гена FLG і на сьогодні вже описано більше 40 мутацій, що специсрічні для різних популяцій та рас $[12,13]$. Найпоширенішими виявилися мутації у третьому екзоні - 2282del4 i R501X. При цьому в європейських регіонах найчастіше реєструють варіанти: R501X, 2282del4, S3247X, 3702delG, R2447X, а в азіатських країнах - 3321delA (Східна Азія) та Q2417X (Тайвань та Китай). Цікаво, що у РФ серед пацієнтів з АД із різною частотою описується поліморфізм R501X, 2282del4, S3247X, R2447X, a от носіїв мутації 3702delG взагалі не виявлено [14, 15]. Наведені дані виразно демонструють різницю в популяційній генетиці FLG між Європою та Азією [16]. 
За розповсюдженістю мутації в гені FLG на хромосомі 1q21 спостерігають у 50-60 \% європейців, які страждають від АД. Водночас, за даними вітчизняних досліджень, мутації R501X та 2282del4 в гені FLG простежують лише у 20,6 \% хворих на АД, що вочевидь не відображає реальної ситуації, але свідчить про недостатнє залучення молекулярно-генетичного аналізу в діагностиці АД [17].

Відкритим залишається питання про роль варіантів поліморфізму FLG у розвитку атопічного маршу. За існуючими даними, мутації FLG (R501X та 2282del4 відповідають за співіснування АД, алергічного риніту, бронхіальної астми, однонуклеотидний поліморфізм SNPs - АД і бронхіальної астми, поліморфізм rs11204981 - бронхіальної астми [18-20].

Зосередження на проблемі у дитячій популяції показало, що нині, на жаль, бракує досліджень, присвячених вивченню ролі поліморфізму FLG при алергопатології у дітей. 3 нечисленних опублікованих даних випливає, що при АД у дітей зі східних країн мутацію FLG 2282del4 реєструють 3 частотою 12,62 \%. У дитячій популяції українців поліморфізм FLG rs11204981 описаний у дітей, хворих на бронхіальну астму, при цьому 5 \% пацієнтів мають мінорну алель, $27 \%$ - гетерозиготну алель та $67 \%$ - мажорну алель [18, 21].

МЕТА ДОСЛІДЖЕННЯ - ВИВчити особливості поєднаного перебігу атопічного дерматиту і бронхіальної астми у дітей за умов генетичного поліморфізму білка фрілагрину.

МАTЕРІАЛИ ТА МЕТОДИ. У дослідження було залучено та обстежено 51 дитину з атопічним дерматитом віком від 3 до 12 років. Пацієнтів поділено на репрезентативні за віком і статтю групи. Першу групу склали діти з атопічним дерматитом, другу - діти з атопічним дерматитом та супутньою бронхіальною астмою. Діагноз атопічного дерматиту та бронхіальної астми встановлені відповідно до чинних вітчизняних та міжнародних настанов. Задля визначення поліморфрізму гена FLG R501XAA та 2282de4AA при АД у дітей досліджували букальний епітелій. Виділення та очищення ДНК із букальних клітин проводили за методом Делапорта (1983). 3 метою оцінки якості життя дітей використовували опитувальники на основі CDLQI (індекс якості життя дитини при дерматологічних захворюваннях); для дітей віком від 3 до 7 років; для дітей віком від 7 до 12 років. Алергологічні тести проводили за методиками in vitro для визначення рівня специфрічних $\lg \mathrm{E}$.
РЕЗУЛЬТАТИ ДОСЛІДЖЕННЯ ТА ЇХ ОБГОВОРЕННЯ. В обстежених дітей найчастіше при АД спостерігали варіант поліморфізму $R 501 X-(78,4 \pm 5,76) \%$, що збігається 3 результатами, представленими при обстеженні дорослих із АД. При цьому варіант із делецією 2282del4 реєстрували у $(7,8 \pm 3,76) \%$, а компаундну гетерозиготність - у $(13,7 \pm 4,81) \%$ пацієнтів. Варіанти розподілу алельних варіантів FLG в обстежених дітей наведено в таблиці 1.

Як видно з наведених у таблиці 1 результатів, варіанти поліморфізму гена FLG у дівчаток та хлопчиків розподілилися майже однаково: в обох групах переважала мутація R501XAa. Незначне збільшення мутацій 2282del4del спостерігали у хлопчиків, у той час як комбінований варіант був представлений з однаковою частотою, незалежно від гендерної ознаки.

3 огляду на концепцію атопічного маршу особливу увагу приділяли вивченню супутніх алергічних захворювань, у структурі яких перше місце посідала бронхіальна астма. Достеменної різниці за нозологіями алергічної природи залежно від віку не встановлено ( $>>0,05)$. Проте варто зазначити, що у дітей старшої групи алергічний риніт та БА спостерігали частіше, що вказувало на реалізацію АМ (табл. 2).

Рівень маркерів алергічного запалення не зазнавав істотного впливу за умов прогресування АМ, при цьому в загальній когорті еозинофілію задокументовано у $(14,6 \pm 3,74) \%$, підвищення сироваткової концентрації $\lg \mathrm{E}-$ в $(61,8 \pm 5,2) \%$ дітей.

Вивчення особливостей перебігу АД за умов генетичного поліморфізму FLG продемонструвало асоціативний зв'язок із тяжким перебігом захворювання у $(54,9 \pm 6,97) \%$ дітей $\left(X^{2}=16,2, p<0,05\right)$. Аналізуючи характер захворювання залежно від варіанта поліморфізму FLG, встановлено обтяження перебігу АД за наявності R501XAa 2282del4 або R501XAA 2282del4del у $(50,0 \pm 4,9) \%$, а при комбінації вказаних мутацій тяжкий перебіг виявлено більш ніж у 70 \% пацієнтів. Перебіг середньої тяжкості діагностовано при R501XAA 2282del4del у $(25,0 \pm 4,3) \%$ дітей, при R501XAa 2282del4 - в $(32,5 \pm 4,8) \%$. Необхідно зазначити, що легкий перебіг АД за умов комбінації R501XAa i 2282del4del не реєстрували в жодному з випадків.

При вивченні особливостей поліморфізму гена фрілагрину в групах порівняння достеменної різниці не встановлено. В обох групах спостерігали ранню

Таблиця 1. Гендерний розподіл алельних варіантів FLG у дітей

\begin{tabular}{|l|c|c|c|c|}
\hline \multicolumn{1}{|c|}{ Генотип } & R501XAA 2282de4AA & R501XAa 2282del4AA & $\begin{array}{c}\text { R501X Aa } \\
\text { 2282del4del }\end{array}$ & $\begin{array}{c}\text { R501X AA } \\
2282 d \text { del4del }\end{array}$ \\
\hline Дівчатка, \% & $57,9 \pm 6,6$ & $28,0 \pm 6,0$ & $8,8 \pm 3,7$ & $5,3 \pm 2,9$ \\
\hline Хлопчики, \% & $51,9 \pm 6,8$ & $33,3 \pm 6,4$ & $7,4 \pm 3,6$ & $7,4 \pm 3,6$ \\
\hline
\end{tabular}

Таблиця 2. Спектр супутньої патології алергічної природи у дітей з атопічним дерматитом за наявності поліморфізму в гені $F L G$

\begin{tabular}{|l|c|c||}
\hline \multirow{2}{*}{\multicolumn{1}{|c|}{ Супутня патологія }} & \multicolumn{2}{c|}{$\begin{array}{c}\text { Пацієнти з АД } \\
\text { (n=51) }\end{array}$} \\
\cline { 2 - 3 } & $\mathrm{n}$ & $\mathrm{M} \pm \mathrm{m}, \%$ \\
\hline Харчова алергія & 18 & $35,3 \pm 6,7$ \\
\hline Бронхіальна астма & 20 & $38,0 \pm 6,8$ \\
\hline Алергічний риніт & 3 & $5,7 \pm 3,2$ \\
\hline Інші алергічні захворювання & 11 & $20,9 \pm 5,7$ \\
\hline
\end{tabular}


маніфестацію атопічного дерматиту $((80,6 \pm 7,2) \%$ в групі АД та $(80 \pm 8,9) \%$ в групі АД/БА). При вивченні спектра сенсибілізації встановлено, що в групі АД/БА сенсибілізовано до епідермальних алергенів $(70 \pm 10,3) \%$ пацієнтів, а в групі АД $(51,7 \pm 6,6) \%(p>0,05)$. Гіперчутливість до пилкових алергенів достеменно частіше спо-

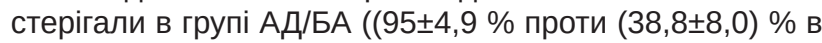
групі АД, р<0,05). Це, очевидно, відображає значущість інгаляційних алергенів у реалізації алергічного запалення дихальних шляхів. Хоча й не було встановлено статистичної достовірності, сенсибілізацію до грибкових алергенів частіше реєстрували в групі АД/БА $((80,0 \pm 8,9) \%$ на противагу $(51,7 \pm 6,6) \%$ в групі АД, р>0,05. Харчову алергію достеменно частіше спостерігали у пацієнтів групи АД $(p<0,05)$. Зменшення ролі харчових алергенів у пацієнтів групи АД/БА, напевно, пов'язано з тривалими елімінаційними заходами, що сприяли зниженню рівня сенсибілізації. Значимість кліщів домашнього пилу в спектрі сенсибілізації була вищою в групі АД/БА, хоча статистична достовірність не доведена $(p>0,05)$.

Це показує, що антигенний вплив через ушкоджену шкіру є достатнім, щоб викликати системне (Th2) алергічне запалення у різних системах, та може допомогти пояснити розвиток АМ, в якому АД $є$ найбільш раннім атопічним проявом. Крім того, це підкреслює важливість шкірної сенсибілізації алергенами, навіть якщо алергічне запалення відбувається у віддалених органах.

При визначенні впливу поліморфізму FLG на клінічний перебіг АД було встановлено наявність асоціативного зв'язку з такими показниками: раннім дебютом захворювання $X^{2}=33,2$, переважно тяжким перебігом $X^{2}=16,2$, вираженою сухістю шкіри $\chi^{2}=22,6$, переважною сенси білізацією до грибів $x^{2}=10,6$ та кліщів домашнього пилу $\chi^{2}=12,2$, порушенням мікробіому шкіри $\chi^{2}=7,8$.

\section{СПИСОК ЛІТЕРАТУРИ}

1. Mechanisms of the development of allergy (MeDALL): introducing novel concepts in allergy pheno types / J. M. Anto, J. Bousquet, M. Akdis [et al.] // J. Allergy Clin. Immunol. - 2017. - Vol. 139 (2). - P. 388-399.

2. Kabesch M. Recent findings in the genetics and epigenetics of asthma and allergy / M. Kabesch, J. Tost // Semin . Immunopathol. - 2020. - Vol. 42 (1). - P. 43-60.

3. Levin J. Atopic Dermatitis and the stratum corneum. Part 2: Other structural and functional characteristics of the stratum corneum barrier in atopic skin / J. Levin, S. F. Friedlander, J. Q. Del Rosso // J. Clin. Aesthetet Dermatol. - 2013. - Vol. 6 (11). - P. 49-54.

4. Eczema severity in preadolescent children and its relation to sex, filaggrin mutations, asthma, rhinitis, aggravating factors and topical treatment: a report from the BAMSE birth cohort $/$ N. Ballardini, I. Kull, C. Soderhall [et al.] // Br. J. Dermatol. 2013. - Vol. 168 (3). - P. 588-594.

5. Liang $Y$. The genetics and epigenetics of atopic dermatitisfilaggrin and other polymorphisms / Y. Liang, C. Chang, Q. Lu // Clin. Rev. Allergy Immunol. - 2016. - Vol. 51 (3). - P. 315-328.

6. Portelli M. A. Genetic risk factors for the development of allergic disease identified by genome-wide association / M. A. Portelli, E. Hodge, I. Sayers // Clin. Exp. Allergy. - 2015. - Vol. 45 (1). - P. 21-31.

7. McAleer M. A. The multifunctional role of filaggrin in allergic skin disease / M. A. McAleer, A. D. Irvine // J. Allergy Clin. Immunol. - 2013. - Vol. 131 (2). - P. 280-291.
3 урахуванням важливості індексу якості життя як критерію стану здоров'я та для оцінки індивідуальної реакції дитини на хворобу досліджували цей показник в обох групах дослідження. Більшість хворих зазнавала суттєвого впливу захворювання на якість життя, так у групі АД це встановлено в $(54,8 \pm 6,8) \%$, а в групі АД/БА - у $(95,0 \pm 4,9) \%$ пацієнтів. Середній бал Яж у групі АД

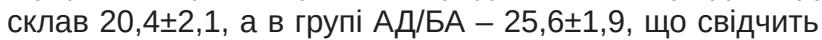
про суттєвий вплив поєднаних алергічних процесів на суб'єктивне сприйняття дитиною тяжкості свого стану та обмежень у життєдіяльності.

ВИСновКИ. 1. Поліморфрізм гена фрілагрину може слугувати інорормативним маркером для прогнозування розвитку бронхіальної астми у дітей з АД.

2. Гіперчутливість шкіри за умов генетично детермінованого десріциту дериватів FLG супроводжується підвищеною сухістю шкіри через транскутанну втрату вологи в роговому шарі шкіри, що впливає на бар'єрні функції, та призводить до надмірного проникнення алергенів, фрормування сенсибілізації та АМ із трансфрормацією в поєднану алергопатологію АД, АР, БА.

3. Рання манісрестація атопічного маршу за умов генетичного поліморфізму R501XAA та 2282de4AA у дітей 3 орілагриноасоційованим атопічним дерматитом потребує відновлення епідермального бар'єру шкіри для запобігання транскутанному проникненню алергенів та ранньої сенсибілізації організму для профрілактики виникнення БА.

ПЕРСПЕКТИВИ ПОДАЛЬШИХ ДОСЛІДЖЕНЬ. ВИвчення особливостей перебігу бронхіальної астми за умов дефректу білка фрілагрину є перспективним напрямком подальших досліджень, що дозволить визначити прогностичні критерії перебігу фрілагринасоційованої бронхіальної астми у дітей та розробити дисреренційовані профрілактично-лікувальні алгоритми.

8. Атопический дерматит у детей: современные клинические рекомендации по диагностике и терапии / Л. С. Намазова-Баранова, А. А. Баранов, А. А. Кубанова [и др.] // Вопросы современной педиатрии. - 2016. - № 15 (3). - С. 279-294.

9. Волосовец А. П. Роль филлагрина в аллергологии детского возраста / А. П. Волосовец, С. П. Кривопустов, Е. В. Павлик // Здоровье ребенка. - 2013. - № 2. - С. 12-15.

10. Lodén M. Treatments improving skin barrier function / M. Lodén // Curr. Probl. Dermatol. - 2016. - Vol. 49. P. 112-122.

11. Беш Л. В. Атопічні дерматити у дітей: аналіз діагностичних і тактичних помилок / Л. В. Беш // Здоров'я України. - 2013. - Алергологія : тематичний номер. - С. 52-53.

12. Mutations in the gene filaggrin in patients with atopic dermatitis as a risk factor for the severity of the disease I I. I. Balabolkin, I. A. Larkova, V. A. Bulgakova [et al.] // Allergy. - 2016. - Vol. 71 (S102). - P. 300-301.

13. Калюжная Л. Д. Разнообразие топической терапии атопического дерматита как фрактор преодоления кортикофобии / Л. Д. Калюжная // Клиническая иммунология. Алергология. Инфектология. - 2014. - № 8 (77). C. $19-23$.

14. Atopic eczema and fracture risk in adults: A populationbased cohort study / K. E. Lowe, J. Zein, U. Hatipoglu, A. Attaway // J. Allergy Clin. Immunol. - 2020. - Vol. 145 (2). - P. 563-571. 
15. Dennin M. Filaggrin and childhood eczema / M. Dennin, P. A. Lio // Arch. Dis. Child. - 2017. - Vol. 102 (12). P. 1101-1102.

16. Kim K. H. Overview of atopic dermatitis / K. H. Kim // Asia Pac. Allergy. - 2013. - Vol. 3 (2). - P. 79-87.

17. Association between $\mathrm{P} 478 \mathrm{~S}$ polymorphism of the filaggrin gene \& atopic dermatitis / S.-Y. Kim, S. W. Yang, H.-L. Kim [et al.] // Indian J. Med. Res. - 2013. - Vol. 138 (6). - P. 922-927.

18. Зуева М. И. Мутации R501X и 2282del4 гена FLG y больных аллергодерматозами [Електронний ресурс] / М.И.Зуева // Вісник Харківського національного університету імені В. Н. Каразіна. - 2011. - Вип. 13, № 947. - С. 93-97. (Серія «Біологія»). - Режим доступа : http://nbuv.gov.ua/UJRN/ VKhb_2011_947_13_16.

\section{REFERENCES}

1. Anto, J.M., Bousquet, J., Akdis, M., Auffray, C., Keil, T., Momas, I., ..., \& Xu, C.J. (2017). Mechanisms of the development of allergy (MeDALL): introducing novel concepts in allergy pheno types. J. Allergy Clin. Immunol., 139 (2), 388-399. DOI: 10.1016/j. jaci.2016.12.940

2. Kabesch, M., \& Tost, J. (2020). Recent findings in the genetics and epigenetics of asthma and allergy. Semin. Immunopathol., 42 (1), 43-60. DOI: 10.1007/s00281- 01900777-w

3. Levin, J., Friedlander, S.F., \& Del Rosso, J.Q. (2013). Atopic dermatitis and the stratum corneum. Part 2: Other structural and functional characteristics of the stratum corneum barrier in atopic skin. J. Clin. Aesthet. Dermatol., 6 (11), 49-54.

4. Ballardini, N., Kull, I., Söderhäll, C., Lilja, G., Wickman, M. \& Wahlgren, C.F. (2013). Eczema severity in preadolescent children and its relation to sex, filaggrin mutations, asthma rhinitis, aggravating factors and topical treatment: a report from the BAMSE birth cohort. Br. J. Dermatol., 168 (3), 588-594. DOI: 10.1111/bjd.12196.

5. Liang, Y., Chang, C., \& Lu, Q. (2016). The genetics and epigenetics of atopic dermatitis-filaggrin and other polymorphisms. Clin. Rev. Allergy Immunol., 51 (3), 315-328. DOI: $10.1007 / \mathrm{s} 12016-015-8508-5$.

6. Portelli, M.A., Hodge, E., \& Sayers, I. (2015). Genetic risk factors for the development of allergic disease identified by genome-wide association. Clin. Exp. Allergy, 45 (1), 21-31. DOI: $10.1111 /$ cea.12327.

7. McAleer, M.A., \& Irvine, A.D. (2013). The multifunctional role of filaggrin in allergic skin disease. J. Allergy Clin. Immunol., 131 (2), 280-291. DOI: 10.1016/j.jaci.2012.12.668.

8. Namazova-Baranova, L.S., Baranov, A.A., Kubanova, A.A., Ilina, N.I., Kurbacheva, O.M., Vishneva, E.A., ..., \& Voznesenskaya, N.I. (2016). Atopic dermatitis in children: current clinical guidelines for diagnosis and therapy. Curr. Pediatrics, 15 (3), 279-294. DOI: https://doi.org/10.15690/vsp.v15i3.1566.

9. Volosovets, A.P., Krivopustov, S.P., \& Pavlik, Ye.V. (2013). Rol fillagrina $v$ allergologii detskogo vozrasta [The role of phillagrin in allergology of children]. Zdorovye rebenka - Child Health, 2, 12-15 [in Russian].

10. Lodén, M. (2016). Treatments improving skin barrier function. Curr. Probl. Dermatol., 49, 112-122. DOI: $10.1159 / 000441586$.

11. Besh, L.V. (2013). Atopichni dermatyty u ditei: analiz diahnostychnykh i taktychnykh pomylok [Atopic dermatitis in children: analysis of diagnostic and tactical errors]. Zdorovia
19. Дитятковський В. О. Атопічний марш у педіатрії: генотип-асоційовані механізми. Частина 1. Генотип-асоційовані механізми хвороб атопічного маршу в дітей [Електронний ресурс] / В. О. Дитятковський // Здоров'я дитини. - 2017. - Т. 12, № 4. - С. 498-504. - Режим доступу : http:// nbuv.gov.ua/UJRN/Zd_2017_12_4_14 DOI: 10.22141/22240551.12.4.2017.107632.

20. Функціональне значення однонуклеотидного поліморфізму (rs11204981) в гені фрілагрину (FLG) для лікування бронхіальної астми у дітей з атопічним дерматитом / О. П. Волосовець, В. Є. Досенко, С. П. Кривопустов [та ін.] // Здоровье ребёнка. - 2015. - № 1 (60). - С. 14-18.

21. Correlation of age-of-onset of atopic dermatitis with filaggrin loss-of-function variant status / S. P. Smieszek, S. Welsh, C. Xiao [et al.] // Sci. Rep. -2020. - Vol. 10 (1). - P. 2721.

Ukrainy. Tematychnyi nomer, alerholohiia - Health of Ukraine. Thematic Issue, Allergology., 52-53 [in Ukrainian].

12. Balabolkin, I.I., Larkova, I.A., Bulgakova, V.A., Pinelis, V.G., Gusar, V.A., \& Janin, I.S. (2016). Mutations in the gene filaggrin in patients with atopic dermatitis as a risk factor for the severity of the disease. Allergy, 71 (S102), 300-301. Retrieved from: https:// onlinelibrary.wiley.com/doi/epdf/10.1111/all.12974.

13. Kalyuzhnaya, L.D. (2014). Raznoobraziye topicheskoy terapii atopicheskogo dermatita kak faktor preodoleniya kortikofobii [Variety of topical therapy for atopic dermatitis as a factor in overcoming corticophobia]. Klinichna imunologiya. Alergologiya. Infektologiya - Clinical Immunology. Allergology. Infectology, 8 (77), 19-23 [in Russian].

14. Lowe, K.E., Zein, J., Hatipoglu, U., \& Attaway, A. (2020). Atopic eczema and fracture risk in adults: A population-based cohort study. J. Allergy Clin. Immunol., 145 (2), 563-571. DOI: 10.1016/j.jaci.2019.09.015.

15. Dennin, M., \& Lio, P.A. (2017). Filaggrin and childhood eczema. Arch. Dis. Child., 102 (12), 1101-1102. DOI: 10.1136/ archdischild-2017-313010.

16. Kim, K.H. (2013). Overview of atopic dermatitis. Asia Pac. Allergy, 3 (2), 79-87. DOI: https://doi.org/10.5415/apallergy.2013.3.2.79.

17. Kim, S.Y., Yang, S.W., Kim, H.L., Kim, S.H., Kim, S.J., Park, S.M., ..., \& Um, J.Y. (2013). Association between P478S polymorphism of the filaggrin gene \& atopic dermatitis. Indian J. Med. Res., 138 (6), 922-927.

18. Zuyeva, M.I. (2011). Mutatsii R501X i 2282del4 gena FLG u bolnykh allergodermatozami [R501X and 2282del4 mutations of FLG gene in allergodermatoses patients]. Visnyk Kharkivskoho natsionalnoho universytetu imeni V. N. Karazina. Seriya: Biolohiya - Bulletin of V.N. Karazin Kharkiv National University. Series: Biology, 13 (947), 93-97. Retrieved from: http://nbuv.gov.ua/UJRN/VKhb_2011_947_13_16 [in Russian].

19. Dytiatkovskyi, V.O. (2017). Atopichñyi marsh u pediatrii: henotyp-asotsiiovani mekhanizmy. Chastyna 1. Henotypasotsiiovani mekhanizmy khvorob atopichnoho marshu v ditei [Atopic march in pediatrics: genotype-associated mechanisms. Part 1. Genotype-associated mechanisms of the atopic march in children]. Zdorovia dytyny - Child Health, 12 (4), 498-504. Retrieved from: http://nbuv.gov.ua/UJRN/Zd 2017_12 414 . DOI: 10.22141/2224-0551.12.4.2017.107632 [in Ukrainian]

20. Volosovets, O.P., Dosenko, V.Ye., Kryvopustov, S.P., Pavlyk, O.V., Yemets, O.V., \& Stroi, D.O. (2015). Funktsionalne znachennia odnonukleotydnoho polimorfizmu (rs11204981) v 
heni filahhrinu (FLG) dlia likuvannia bronkhialnoi astmy u ditei $z$ atopichnym dermatytom [Functional significance of singlenucleotide polymorphism (rs11204981) in filaggrin (flg) gene for the treatment of bronchial asthma in children with atopic dermatitis]. Zdorovye rebenka - Child Health, 1 (60), 14-18 [in Ukrainian].
21. Smieszek, S.P., Welsh, S., Xiao, C., Wang, J., Polymeropoulos, C., Birznieks, G., \& Polymeropoulos, M.H. (2020). Correlation of age-of-onset of atopic dermatitis with filaggrin loss-of-function variant status. Sci. Rep., 10 (1), 2721. DOI: 10.1038/s41598-020-59627-7.

Отримано 02.03.21 Прийнято до друку 08.04.21 Електронна адреса для листування: natalyvesilyk@ukr.net 